\title{
MATERIALS FOR PRODUCTION OF PROTECTIVE BOOTS FOR WORKERS IN FORESTRY
}

\author{
Miroslav Mikulčić' ${ }^{1}$ Stana Kovačević Zenun Skenderi², \\ JELEN PROFESSIONAL d.o.o., Čakovec ${ }^{1}$ \\ University of Zagreb Faculty of Textile Technology2 \\ Department of Textile Design and Management ${ }^{2}$
}

E-mail: stana.kovacevic@ttf.hr

Proffesional paper

UDK: [685.34.03:614.897]:630

\begin{abstract}
The effectiveness of forestry boots depends primarily on the materials of which they are made, the manner and location of incorporation. The use of highly sophisticated materials, highly developed technological processes and knowledge-based development provide a good basis for the production of quality forestry boots. This paper gives an overview of the technological phases of manufacturing forestry boots that meet the standards defining full human protection against mechanical and other injuries when using motor saws and possible crushing. The complexity of the manufacturing process of forestry boots is reflected in the use of special high-quality materials, their functions, and how to incorporate them into in the boot. To achieve full protection of the foot and lower leg, the forestry boot contains multi-layered advanced composite materials, appropriately processed leather, fabrics, steel, non-woven textiles, and waterproof and vapour-permeable membranes.
\end{abstract}

\section{Keywords}

forestry boot, leather, Kevlar fabric, Cordura $₫$ fabric, Sympatex $®$ membrane, manufacturing process

\section{Introduction}

Protective footwear should be safe, functional, comfortable to wear, health-friendly and made of quality materials. The protective effect of footwear mostly depends on the characteristics of the material of which it is made as well as on the type of footwear manufacturing process. The current forestry work technology unfortunately endangers the health of workers, so that these operations are at the top of the risk of human injury. Opportunities are particularly worrying in the private sector. In order for a forest worker to have satisfactory safety at work, it is essential that he possesses special skills and competences, sufficient working experience, suitable working tools, good working conditions and properly selected personal protective equipment. The most frequent accident factor is the incorrect use of the power saw. Due to the specificity of forestry production, personal protective equipment is indispensable and cannot be replaced by other methods of protecting workers at work. Working with a manually guided chainsaw is highly risky. In addition to high levels of noise and vibrations, there is also a risk of possible cuts. Analyses indicate that forestry work-related injuries in the form of cuts are frequent and according to frequency of injuries in forestry they rank second, immediately after injuries inflicted by falling tree trunks, logs or branches and the like. The most endangered parts of the body are legs and arms, so it is necessary to protect them particularly.
Previous practice has shown that the body of the operator of the hand-held chain saw can be relatively successfully protected by use of clothing and other personal protective equipment defined by the appropriate standards [1].

However, it should be emphasized that personal protective equipment cannot provide $100 \%$ protection against the hand-held chainsaw. Therefore, the importance of correct exercise and the need for a correct working procedure cannot be overemphasized [2].

\section{Definition and classification of protective footwear}

Protective footwear includes work safety shoes, work safety ankle-boots and boots made of leather, rubber or synthetic materials or combinations of these materials. The basic parameters of work safety footwear are:

- Resistance to: punching, oil, gasoline, mechanical shocks and slipping.

- Shock absorption: footwear should be provided with a shock absorber on the heel due to the construction of the sole and the inner sole.

- Waterproofness and water vapour permeability of the lining (e.g. Sympatex® and GORE-TEX® materials).

- Thermal insulation: footwear should prevent the penetration of high and low temperatures. 
Safety footwear is used: to protect legs, against falling heavy objects on the legs, stabs and cutting, slipping, grease, oils and chemicals. Additional protections are incorporated for targeted protection such as steel toe caps, impenetrable insole, puncture resistant sole, heel, ankle and shin protection, antistatic tapes etc. This kind of footwear should not be heavy and uncomfortable, i.e. it should be designed in accordance with ergonomic standards or requirements. To protect the legs while working with hand-held power saws and other similar work processes, it is recommended, in addition to appropriate safety and protective footwear, to use shin guards additionally.

Safety footwear with resistance to chain saw cutting can be divided into classes according to standard HRN EN ISO 17249:2013, Table 1 [3].

Table 1 Division of safety footwear according to classes

\begin{tabular}{|c|c|c|}
\hline \multicolumn{3}{|c|}{ HRN EN ISO 17249:2013 - Safety footwear with } \\
resistance to chain saw cutting
\end{tabular}

For the protection of legs and feet the following footwear types are used:

- Safety footwear: footwear with incorporated safety cap for toe protection for large loads tested with impact energy up to $200 \mathrm{~J}$. This type of footwear should meet the requirements of standard HRN EN ISO 20345 - Personal protective equipment Safety footwear [4].

- Protective footwear: footwear with incorporated protective cap for toe protection for medium loads tested with impact energy up to $100 \mathrm{~J}$. This type of footwear should meet the requirements of standard HRN EN ISO 20346 - Personal protective equipment - Protective footwear [5].

- Personal protective equipment or occupational footwear: footwear without protective shoe cap, but it contains one or several protective components. It is used for work in areas where the risk of mechanical injuries is kept to minimum. This kind of footwear should meet the requirements of standard HRN EN ISO 20347 - Personal protective equipment - Occupational footwear [6].

Protective footwear can be divided into two classes regarding the manufacturing material:

Class I - footwear made of leather or other materials, besides the footwear which is completely made of natural or synthetic polymers.

Class II - rubber footwear (completely vulcanized) or footwear made of natural or synthetic polymers (completely injected).

The basic material used for manufacturing protective footwear for forest workers is high-quality natural leather with a thickness of 2.3 to $2.5 \mathrm{~mm}$. Part of the manufacturing technology for low work safety footwear and high work safety footwear is described in papers [7, 8]. Furthermore, the comfort of leather footwear and the measurement of thermo physical parameters (thermal resistance and water vapour resistance) were also elaborated and commented in papers $[9,10]$.

Protective bovine leather is hydrophobic and fireproof, resistant to liquids and abrasion. As the basic material CORDURA $\AA$ can also be used, which, together with leather, is also used for some parts of footwear, the upper part of the boots or the part around the ankle and as reflective tapes.

\section{Textile and composite materials incorporated into protection boots for forest workers}

To ensure the functionality of the footwear, it is important to choose appropriate materials that will provide protection and wear comfort. The basic footwear material is leather and rubber. Protective footwear also contains other materials such as fabric, composite materials, membranes, nonwovens, metals, zippers, sewing threads, buckles or clasps and adhesive tapes, etc. Fibres for making textile materials are selected in accordance with appropriate properties that are determined by the application of the final product. Their functionality has been improved by developing new fibres with improved physicomechanical, chemical and thermal properties and their application in protective footwear. The fibres used today for protective footwear are of different raw materials and properties, such as aramid fibres (Kevlar and Nomex), polyester and polyamide fibres (Table 2) [11-14]. Aramid fibres are obtained from aromatic polyamides, known as heat resistant fibres, meaning they do not lose strength at continuous loads at elevated temperatures. Special mechanical properties, nonflammability and excellent resistance to chemicals are the reason why this fibre group is an extremely highquality material. Kevlar and other para-aramid fibres stand out for strength and are bullet proof and projectile resistant. These multi-layered fabrics are used to make protective vests and ballistic protective clothing. Kevlar is incorporated into safety boots for forest workers (Fig. 1).

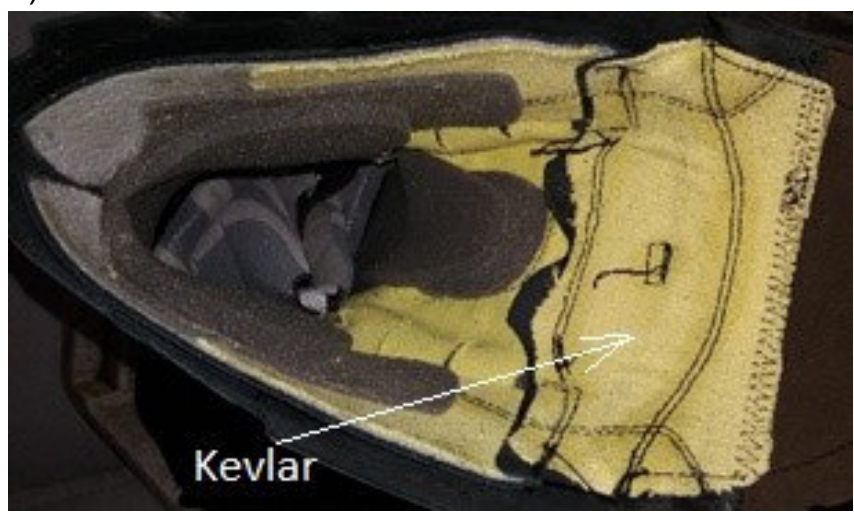

Figure 1 Built in Kevlar fabric in the interior of a protective boots for forestry boots 
Table 2 Comparison of properties of some synthetic fibres

\begin{tabular}{|l|c|c|c|c|c|c|}
\hline \multicolumn{1}{|c|}{ Fibre } & $\begin{array}{c}\text { Density } \\
\mathbf{g} / \mathbf{c m}^{\mathbf{3}}\end{array}$ & $\begin{array}{c}\text { Moisture } \\
\text { absorption, } \\
\mathbf{\%}\end{array}$ & $\begin{array}{c}\text { Strength, } \\
\mathbf{c N} / \mathbf{t e x}\end{array}$ & $\begin{array}{c}\text { Elongation at } \\
\text { break, } \\
\mathbf{\%}\end{array}$ & $\begin{array}{c}\text { Softening } \\
\text { point, } \\
{ }^{\circ} \mathbf{C}\end{array}$ & $\begin{array}{c}\text { Melting point, } \\
\mathbf{}^{\mathbf{C}}\end{array}$ \\
\hline Polyester & $1,36-1,41$ & $0,2-0,5$ & $30-70$ & $20-30$ & $230-240$ & $250-260$ \\
\hline Polyamide 6 & 1,14 & $3,5-4,5$ & $30-90$ & $20-45$ & $180-200$ & $215-220$ \\
\hline Polyamide 6.6. & 1,14 & $3,5-4,5$ & $30-90$ & $20-45$ & $220-235$ & $255-260$ \\
\hline Kevlar & $1,44-1,47$ & 1,5 & $140-250$ & $1-4$ & - & 550 \\
\hline Nomex & 1,38 & 4,5 & $44-53$ & $22-35$ & - & 370 \\
\hline Acrylic & $1,1-1,19$ & $1-1,5$ & $35-50$ & $15-40$ & - & 310 \\
\hline Modacrylic & 1,17 & $3-3,5$ & $17-55$ & $15-60$ & - & 250 \\
\hline Polypropylene & $0,9-0,92$ & 0 & $26-60$ & $15-50$ & $150-160$ & $165-175$ \\
\hline Dynema & $0,9-0,97$ & 0 & $280-360$ & $3-6$ & - & $144-155$ \\
\hline Fluorofiber & $2,1-2,3$ & 0 & $8-18$ & $13-42$ & $180-200$ & $327-260$ \\
\hline Chlorfiber & 1,4 & 0 & $24-27$ & $10-25$ & $65-75$ & $160-200$ \\
\hline Vinilalno & $1,26-1,32$ & $3,5-5$ & $25-36$ & $15-26$ & $75-130$ & $240-260$ \\
\hline Polyimide & 1,41 & 5 & $0-33$ & $19-8$ & & - \\
\hline Elastane & $1,1-1,3$ & $0,5-1,5$ & $5-12$ & $400-700$ & $170-230$ & $230-250$ \\
\hline
\end{tabular}

The innermost lining of the protective footwear should be particularly strong and breathable. As lining materials for manufacturing protective footwear the following materials are used:

- Natural leather (hydrophobic bovine leather)

- Polyamide materials (good physico-mechanical properties, Table 2)

- Sympatex® (waterproof and water vapour impermeable membrane which enables breathability of the foot)

- CORDURA® fabric (extremely resistant to wear and tear and waterproof, it is incorporated into the upper of the of the boot) [15]

- Kevlar fabric (protection against the power saw and mechanical shocks)

- Metallic guards of the front part of the foot (foot protection against the power saw and crushing

- Special material types incorporated into the inside of the boot (water impermeable and exceptionally strong rubber, strong zippers, water impermeable adhesive tapes, shoelaces, etc.).

CORDURA $®$ is a fabric made of polyamide filaments PA 6.6 textured with air jets that are also used for footwear when it is additionally impregnated or laminated (Fig. 2) [15].

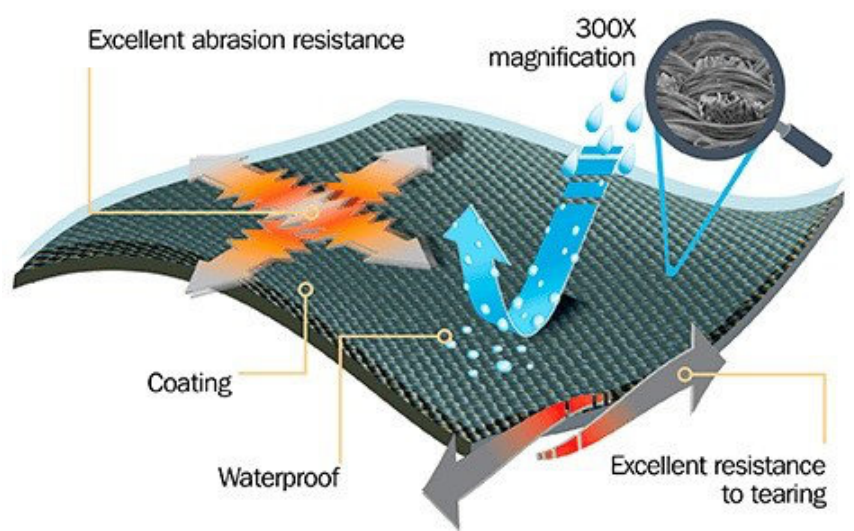

Figure 2 Properties of CORDURA® Classic Fabric [16]
Sympatex® membranes are widely used today in the production of protective footwear. The Sympatex $\circledast$ brand was founded in 1986 by the Dutch multinational company Akzo Nobel Group as a result of the patent of polymer application [17]. In addition, the company ${ }^{\circledR}$ Sympatex Technologies $\mathrm{GmbH}$, Unterföhring, Germany, develops, manufactures and sells membranes, laminates and functional textile products [18]. The main features of the Sympatex® membranes used in the footwear industry are: waterproofness, breathability and excellent comfort. The membranes keep the body dry by controlling the body temperature in all weather conditions and regardless of the level of activity.

Contrary to other technologies of manufacturing membranes, porosity-free compact Sympatex® membrane is based on the physico-chemical principles of behaviour. The water permeable part (hydrophilic) of the membrane absorbs body moisture and transports it out by evaporation. Water vapour molecules are transported outwards along the chains of hydrophilic molecules. The molecular structure (hydrophilic components) of Sympatex® membranes swells in moisture and therefore provides space for water vapour transport and rapid evaporation. This effect increases with increasing temperature and moisture. The partial pressure gradient, which is the result of different temperatures and moisture inside and outside, is actually the force that allows the transport of water vapour through the membrane [18]. Figure 3 shows the designations of individual properties on the products manufactured by Sympatex® technologies [18].

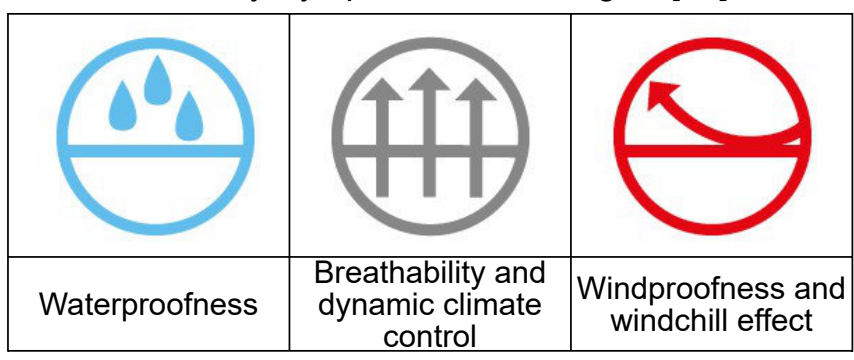


Figure 4 shows an example of using Sympatex ${ }^{\circledR}$ laminates for outdoor activities, trekking and sportswear [19]

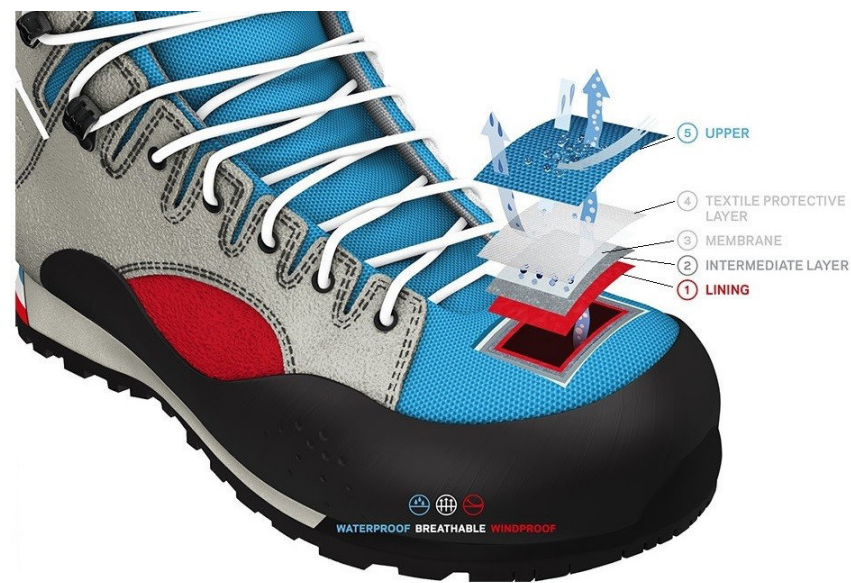

Figure 4 Sympatex ${ }^{\circledR}$ laminates for outdoor activities, trekking and sportswear [19]

The next example is a new four-layered composite for manufacturing the footwear system SYMPATEX MOISTURE-TECH ${ }^{\circledR}$ (patent application No. WO2013050349A) to provide excellent microclimate within the footwear is shown in Figure 5 [20]. Figure 5

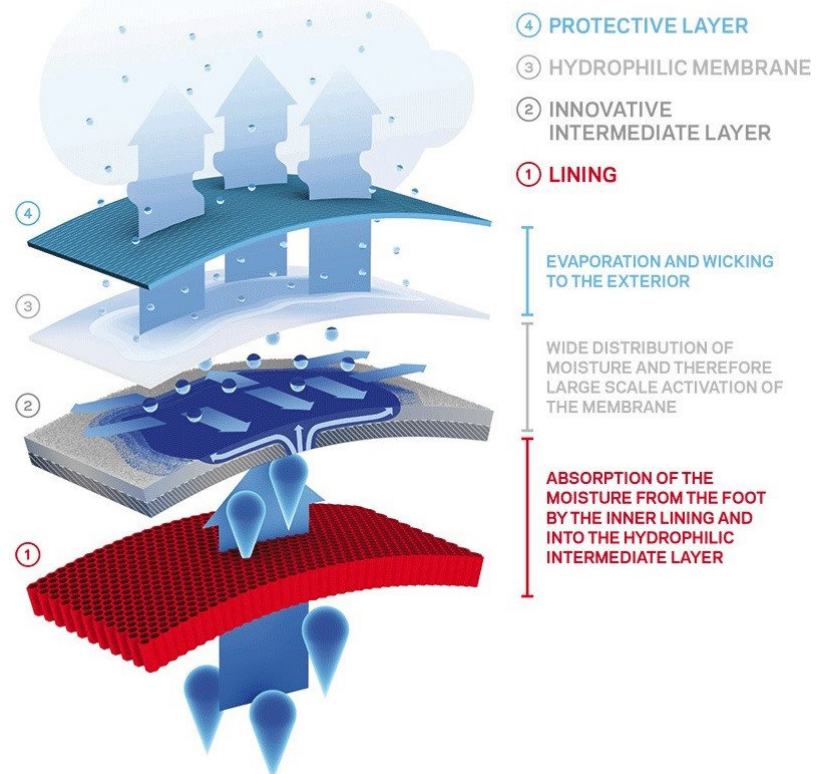

Figure 5 SYMPATEX MOISTURE-TECH $\otimes$ is a new type of waterproof 4-layered laminate which provides excellent microclimate in the footwear [20]

\section{Manufacturing process of forestry safety boots}

The manufacturing process of forestry safety boots is a complex and demanding process. The main boot parts are (Fig. 6):

- Outer leather parts: are made of bovine hydrophobic and fire resistant leather thickness of $2.3-2.5 \mathrm{~mm}$

- Inside of the footwear: made of waterproof and water vapour permeable Sympatex® membrane

- Toe protection: protected with steel toe cap resistant to an impact of $200 \mathrm{~J}$

- Outsole: wear resistant, slip resistant, oil resistant, gasoline resistant, resistant to contact heat of 300

- Insole and sockliner are anatomically formed, boot laces are fire retardant.

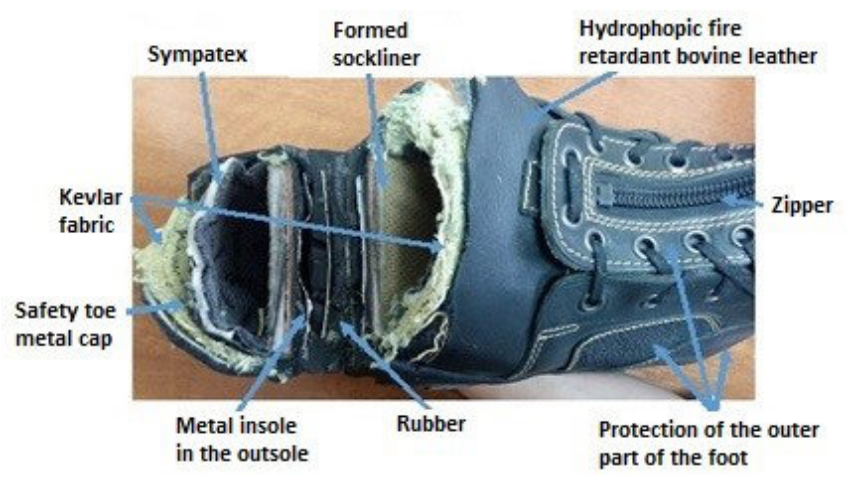

Figure 6 Layers of forestry boot

The following figures show the steps of the manufacturing process of forestry boots (Figure $7-18$ ):

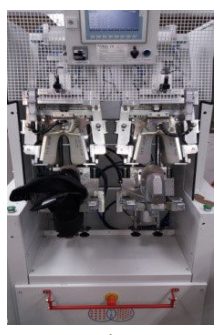

a)

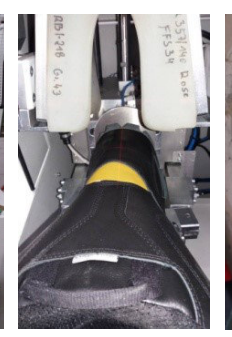

b)

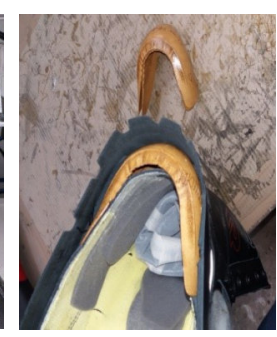

C)

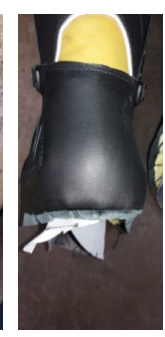

d)

Figure 7 Inserting the counter

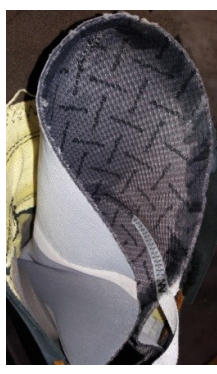

Figure 8

Sympatex®

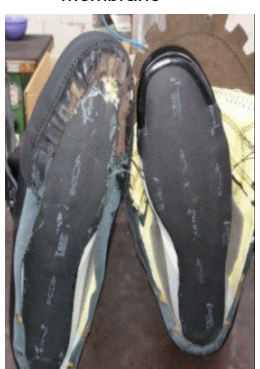

Figure 12 Figure 12
Tweaking

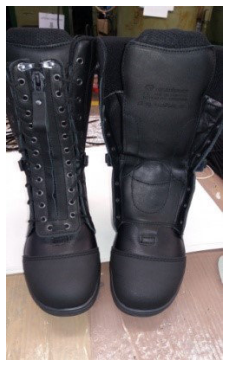

Figure 16 Inserting the boot laces

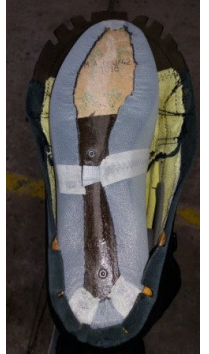

Figure 9 Membrane fixing

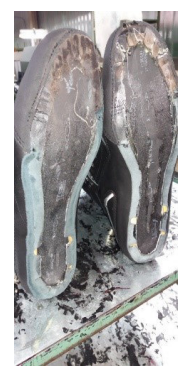

Figure 13 Grinding

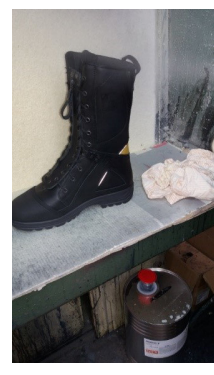

Figure 17
Impregnation

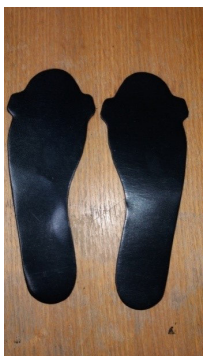

Figure 10 Figure 10
Midsole

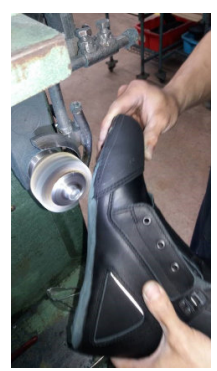

Figure 14 Lateral grinding

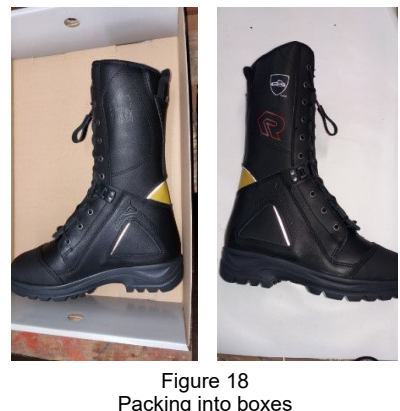

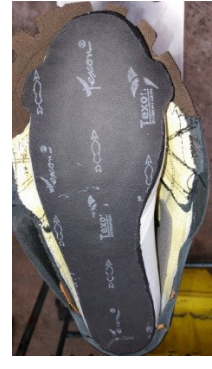

Figure 11 Glued midsole

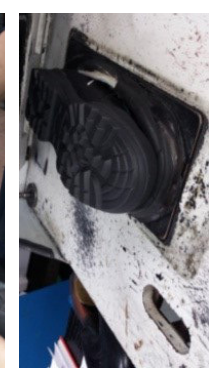

Figure 15 Gluing the outsole ${ }^{\circ} \mathrm{C}$ 


\section{Conclusion}

Some forestry operations are extremely dangerous and detrimental to workers' health. Therefore certain steps and working procedures are regarded as work with increased risk of injury and health damage. After working for a long time, e.g. with the power saw, occupational diseases often occur. By use of new and more efficient materials in the production of forestry safety boots and by meeting the requirements of the prescribed standards, the protection of body parts, feet and shin against power saws, crushing, water and other hazards is achieved. By using a variety of high-quality materials combined into one product, extraordinary comfort is achieved during prolonged wearing. Forestry safety boots are waterproof, flexible, lightweight, providing the forest worker with easy mobility, comfort and protection. By monitoring the process of manufacturing forestry boots, the complexity of manufacturing due to numerous processing steps requiring workers' competence and skills was identified.

\section{Acknowledgment}

This work has been fully supported by Croatian Science Foundation under the project IP-2016-06-5278 (project leader: Zenun Skenderi).

This work has been fully supported by Croatian Science Foundation under the project IP-2018-01-3170 (project leader: Stana Kovačević).

We also thank the companies JELEN PROFESSIONAL d.o.o. Čakovec and Alpschuh $\mathrm{GmbH}$, Edit bei Lambach, Austria, which provided us with basic information on materials and the manufacturing process of safety forestry boots.

\section{References}

[1] HRN EN 381-1:2001 - Protective clothing for users of hand-held chainsaws -- Part 1: Test rig for testing resistance to cutting by a chainsaw to HRN EN 381-11:2003 - Protective clothing for users of hand-held chainsaws -- Part 11: Requirements for upper body protectors

[2] Horvat J., Regent A.: Osobna zaštitna oprema, Polytechnic of Rijeka, Rijeka, 2009., ISBN 978953-6911-43-1.

[3] HRN EN ISO 17249:2013 - Safety footwear with resistance to chain saw cutting

[4] HRN EN ISO 20345 - Personal protective equipment - Safety footwear

http://31.45.242.218/HZN/Todb.nsf/wFrameset2 ?OpenFrameSet\&Frame=Down\&Src $=\% 2 \mathrm{FHZN}$ \%2FTodb.nsf\%2Fcd07510acb630f47c1256d2c0 06ec863\%2F6dfc97f070869638c125773000479 00a\%3FOpenDocument \%26AutoFramed, accessed 15.04.2019.

[5] HRN EN ISO 20346 - Personal protective equipment - Safety footwear
[6] HRN EN ISO 20347 - Osobna zaštitna oprema Sigurnosna obuća

[7] Mikulčić M., Skenderi Z., Akalović J.: Tehnologija proizvodnje niske radno-zaštitne obuće $u$ tt. Jelen Professional d.o.o., 6. Scientific and Professional Consulting Textile Science and Economics TZG 2013, Zagreb, 14. 1. 2013, University of Zagreb Faculty of Textile Technology , Proceedings, ISSN 1847-2877, 5760

[8] Mikulčić M., Skenderi Z., Akalović J.: Proizvodnja visoke radno-zaštitne obuće u tvornici Jelen d.d., Čakovec, Koža \& Obuća, 59 (2012.) 9-12, 28-29.

[9] Kopitar, D.; Akalovic, J.; Skenderi, Z.: Thermal resistance of leather and membranes for summer desert military footwear under different climate conditions, Book of abstracts, Functional Textiles and Clothing Conference, 9th-12th of February 2018, Indian Institute of Technology Delhi, New Delhi India.

[10] Skenderi Z., Mihelić-Bogdanić A., Mijović B.: Thermophysiological wear comfort of footwear, Koža \& Obuća 66 (2017.) 3, 12-21.

[11] http://www.jelen.hr/7314-12350/p26, accessed 15.03.2019.

[12] https://repozitorij.vuka.hr/islandora/object/vuka: 508/preview, accessed 22.03.2019.

[13] http://www.enciklopedija.hr/Natuknica.aspx?ID =61535, accessed 23.03.2019.

[14] Čunko R., Andrassy M.: Vlakna, Zrinski d.d., Zagreb, 2005, UDK 953-155-089-1.

[15] https://www.CORDURA®.com/en/Fabrics/fabrictechnology-explorer, accessed 1.3.2019.

[16] https://www.CORDURA®.com/en/Fabrics/class ic-fabric, accessed 15.04.2019.

[17] https://www.akzonobel.com/en, accessed 1.4.2019.

[18] https://www.Sympatex®.com/en/aboutus/product-and-technology/, accessed 1.04.2019.

[19] https://b2b.sympatex.com/en/footwear/250/out door, accessed 1.4.2019.

[20] https://b2b.sympatex.com/en/technologies/294/ moisture-tech, accessed 5.4.2019. 